\title{
Digital Artifacts as Institutional Attractors: A Systems Biology Perspective on Change in Organizational Routines"
}

\author{
Sung Yong Um ${ }^{1}$, Youngjin Yoo ${ }^{1}$, Nicholas Berente ${ }^{2}$, and Kalle Lyytinen ${ }^{3}$ \\ ${ }^{1}$ Fox School of Business, Temple University, 1810 North 13th Street, Philadelphia, \\ Pennsylvania 19122 \\ \{sungyong.um, youngjin. yoo\} a temple. edu \\ ${ }^{2}$ Terry College of Business, University of Georgia, Athens, Georgia 30602 \\ berente@uga.edu \\ ${ }^{3}$ Department of Information Systems, Case Western Reserve University, \\ 10900 Euclid Avenue, Cleveland, Ohio 44106 \\ kalle@case.edu
}

\begin{abstract}
Digital artifacts have become fundamental elements of organizational change. Such change is not frictionless, since routines and associated structures are deeply embedded- or institutionalized. Though, organizational institutionalism has been traditionally concerned with stability and change in routines and underlying structures, it has so far meagerly theorized the role of digital artifacts in balancing stability and change. To address this gap, we draw on systems biology to understand how introduction of new digital artifacts can influence routines in organizations. In particular, we approach digital artifacts as institutional attractors and examine the role of such attractors within gene regulatory networks. In this view institutional attractors become endogenous to sociomaterial systems and are keys to simultaneously promoting stability and inducing change. Just as attractors are implicated in changes to established gene regulatory networks within cells, so too are digital artifacts implicated in the efforts of institutional entrepreneurs to bring about change to organizational routines (behaviors). Based upon this analogous reasoning we outline elements of a research agenda and conclude with a discussion of methodological directions to deal with digitally induced endogenous sociomaterial change.
\end{abstract}

Keywords: Digital Artifact, Institutional attractor, Institutional change, Systems biology.

\footnotetext{
* This paper is based on work supported, in part, by the National Science Foundation under grants VOSS-0943157 and VOSS-0943010. Any opinions, findings, and conclusions or recommendations expressed in this material are those of the author(s) and do not necessarily reflect the views of the National Science Foundation.
} 


\section{Introduction}

Striking a balance between change and stability has been one of the fundamental concerns of contemporary organizational thinking (Farjoun 2010). "Organizational institutionalism" (Powell \& DiMaggio 1991; Greenwood et al 2008) has a long and rich tradition of heeding to the simultaneous interplay of stability and change. On one hand, organizational actors internalize and continually reproduce established routines in their institutionalized practices thus shaping identities and erecting cultures (Berger \& Luckman 1966; Zucker 1977). Being institutionalized, these routines are difficult to change. On the other hand, organizational actors are under constant pressure to comply with new regulations and normative demands that arise in society that drive change in their routines (DiMaggio \& Powell 1983; Scott 2008). So, organizational actors face constant dilemma of reinventing their organizations without fully divorcing themselves from the institutional logics in which they are deeply embedded.

This 'structurational' (Giddens 1984; Bourdieu 1977) position underlies the bulk of recent thinking on institutional change and institutional entrepreneurship (Powell \& DiMaggio 1991; Seo \& Creed 2002). As a result, organizational institutionalism is one of the most robust theoretical positions for understanding organizational stability and change (Farjoun 2010). However, institutionalism has largely ignored the role of digital artifacts in this process (Jones and Karsten 2008). In fact, Orlikowski and Scott (2008) note that in organizational research, "technology is largely missing in action." Digital artifacts can be defined generally as software-based information technology (IT) that has the capability to mediate and present semiotic relationships (Bailey et al. 2012). Therefore digital artifacts are not comprised primarily of matter but signs. Yet, their existence is not entirely defined in the conceptual domain as their behaviors are founded on material properties of some substrata (such as silicon) and these material features influence their use and applicability. Being sign based digital artifacts are unique in that they are editable, interactive, open, and distributed (Kallinikos et al. 2011; Leonardi 2010). This lack of interest has become recently increasingly problematic, because digital artifacts are deeply embedded in contemporary organizational practices (Baxter \& Berente 2010; Gaskin et al 2011) and constitute essential elements of change in organizational practices (Yoo et al 2006; Zammuto et al 2007).

Institutional theory generally characterizes digital technologies in terms of exogenous forces for change. They can be triggers for social change (Barley 1986); a form of structure that (weakly) enables and constrains new routines (DeSanctis \& Poole 1994); or as carriers of institutional scripts (Scott 2008). In each of these institutionalist conceptualizations, digital artifacts remain exogenous to the practices and go under-theorized and researched. This exogenous characterization of digital artifacts stands also in stark contrast to recent calls to attend to concrete technologiesin-practice (Orlikowski 2000; Leonardi \& Barley 2008) where digital artifacts are viewed as endogenous to the practices. Yet, this thinking has not been reconciled within the dominant institutional discourse. 
In this paper we begin to take some steps reconcile this insight of digital artifacts as endogenous to organizational routines with scholarship on institutional change. In so doing, we draw on recent models of systems biology (Kauffman 1993; Crombach \& Hogeweg 2008). Because the field of systems biology is concerned with conditions of endogenously triggered probabilistic (and often chaotic) change, it provides an appropriate analogue for investigating organizational change (Kitano 2002). The way the systems biology field combines the study of sequence patterns (described by proteins) with the study of networks (genes) (Kauffman 1993) is quite similar to task faced by an institutional theorist grappling with the way the role of digital artifacts in institutional change. The presence of simultaneous change and stability is enabled through the interactions of digital artifacts with organizational structures (networks) and routines of actions (sequences) (Contractor et al 2011; Pentland et al 2008).

In systems biology, a gene regulatory network offers the main explanation for how the same DNA sequence can produce variety of differently functioning cells and their mutations. In particular, genetic regulatory networks coordinate how genes are activated in cells. This perspective is based on the notion of attractors which 'tip' the activation of genes to specific trajectories and lead to changes in cell behaviors. An attractor, a type of 'rogue' or 'heterogeneous' gene, triggers a mutation of a gene structure, and the structure then stabilizes around that attractor. In viewing organizational change as a highly dynamic process, conceptualizing digital artifacts as attractors offers a powerful way of accounting for endogenous change in organizations. Therefore, rooted in this analogue of genetic regulators, we conceive of digital artifacts as institutional attractors. Institutional attractors initiate shake ups in organizational routines and catalyze configurations of how 'social' and 'technological' elements become meshed in organizational routines.

The idea of an institutional attractor combines two distinct elements of digital artifacts that simultaneously explain both the generativity of that artifact in a particular context (Avital et al 2009) and the regularities it expresses across contexts (Robey \& Boudreau 1999). Generativity is defined here as the capacity of digital artifacts to trigger unprompted changes driven by varied and uncoordinated behaviors (Zittrain 2006). Institutional attractors in the form of digital artifacts within organizational networks can thus enable generativity that leads to unprompted changes in activity by forming unexpected connections between actors and activities. Thereby generative artifacts become new attractors that can contribute to the explication of change both symbolically and materially (Leonardi \& Barley 2008) in ways that create different practices. The attractors can also be enacted in ways that are consistent with existing pluralistic logics thus reinforcing institutions (Berente \& Yoo 2012). The generativity can thus reinforce certain elements of institutional structures, while at the same time bringing about new practices that can result in a maelstrom of changes in the institutional order over time. In an organizational context, an institutional attractor can be an artifact whose affordances are enacted by organizational actors in order to bring about either change or stability in organizational routines in a manner consistent with particular institutional logics. The idea of attractors places the focus on complex, chaotic and probabilistic changes enabled by various local interactions with the digital artifacts and broader institutional elements. 
The goal of this paper is to introduce the idea of digital artifacts as institutional attractors and discuss the consequences of such approach in the study of organizational change enabled by digitalization. First, we will review the literature on institutional change and the ways organizational institutionalism has accounted for digital artifacts. Second, we introduce the idea of gene regulatory networks and discuss how they can be used to explain endogenous organizational change. Then we combine these two streams and analyze the digital artifact as an institutional attractor. We conclude with a discussion on the implications of this perspective on research into organizational change - particularly the recent work on sociomateriality and sociomaterial routines.

\section{Institutional Change and Digital Artifacts}

An institution is a reproduced pattern of activity that is both objectified and internalized by actors in a given context (Berger \& Luckman 1967; Jepperson 1991). Institutions are objectified when their representations have meaning (i.e. the institution has a name like "marriage," "army" or "handshake"). An institution is internalized when it is chronically reproduced by actors enacting established scripts through their practices (Giddens 1984). Thus actors reinforce existing institutions with their actions, leading to stability (Zucker 1977). However, as institutions are reinforced in certain contexts, at the same time, they are diffused to other contexts, bringing about change to those other contexts (DiMaggio \& Powell 1983). Thus, institutional analysis is centrally concerned with the both stability and change.

Organizational institutionalism is concerned with stability in that it emphasizes the way established institutions are difficult to change (Zucker 1977). When a pattern of action is well-established, alternative patterns of action may be less legitimate or deemed inappropriate (Selznik 1996). Legitimate courses of action enable access to resources and often protect the actor from external scrutiny. Therefore, actors may enact established, legitimate institutions no matter how poorly they are served by the institutions (DiMaggio \& Powell 1983; Meyer \& Rowan 1977). Further, it requires effort to create new courses of action, and actors economize by enacting ready-made scripts and typifications that come complete with social meaning (Goffman 1969). Finally, much of human activity is unreflected-upon and actors enact institutions habitually (Giddens 1984).

At the same time, organizational institutionalism is concerned with change in that it emphasizes the way institutions diffuse across a field and put pressure on organizational actors to change existing patterns of activity to be isomorphic with others in the field (DiMaggio \& Powell 1983). Different contexts are different, and actors must continually translate existing institutional scripts into novel, idiosyncratic environments - resulting in change and bifurcation of those institutions over time (Czarniawska \& Sevon 1996). Further, situated actions and accidents can lead to unintended consequences that result in change to the existing institutional order (Giddens 1984). In addition, society is institutionally plural (Kratz \& Block 2008) in that it is comprised of multiple levels of institutions whose guiding logics may be 
more or less congruent with each other (Friedland \& Alford 1991; Thornton \& Ocasio 2008). As the salience of logics ebb and flow across contexts, and as contradictory institutions collide, the result is change to institutions over time (Seo \& Creed 2002). Institutional entrepreneurs reflectively draw upon logics different than those established in a given domain to bring about change to that domain (Garud et al 2002). Institutional entrepreneurs can thus mobilize various resources such as structures and technological standards in order to change the very institution in which they are deeply embedded (Rao 2000, Garud et al. 2002).

While it is generally understood that institutional entrepreneurs can play significant roles in bringing about changes in organizations, not every individual action leads to a large change. We still lack a clear theoretical understanding when and how actions taken by institutional entrepreneurs lead to large-scale organizational changes. This, in particular, is an important question for information systems scholars as digital technology is often introduced as a potential catalyst for organizational change (Teece 1995). For example, Garud and associates (2002) show that a technological standard can define how heterogeneous product components are combined together to work in an integrated system within an existing institutional space.

There are three broad ways that institutional theory characterizes digital technologies and their role in change. The first and classic response is to bypass deterministic thinking about technology induced change and looks at digital artifacts as "triggers" structural social change (Barley 1986). In this conception, IT artifacts becomes a change catalyst, but the change itself happens idiosyncratically in the social domain - outside the world of technologies. In another, more recent conception, digital artifacts can act as a form of structure that 'softly-deterministically' brings about change in agent's behaviors when augmented with complementary practices (DeSanctis \& Poole 1994). Finally, digital artifacts can be considered to be "carriers" of institutions - in that they symbolically represent institutional change and embody scripts for new patterns of action (Scott 2008). Organizational actors can then adopt, resist, or loosely couple their practices from those scripts implied by particular digital artifacts based upon the (in)congruence of multiple and competing institutional logics (Berente \& Yoo 2012). In each conceptualization, digital artifacts are exogenous factors that cause an institutional change. As a result, technology and institutional entrepreneur's actions are kept separate (Orlikowski 2008).

What we need is an evolutionary perspective that embraces digital technology and actions by organizational actors as institutional entrepreneurs endogenously. In this way we can understand how certain changes emerge within organizations that lead to large-scale institutional reconfigurations (Van de Ven and Poole 1995). As organizations always inhabit contested fields (Dunn \& Jones 2010), these changes will only emerge from multiple events and related elements that sometimes complement, and other times compete with one another (Berente \& Yoo 2012). Therefore, a theoretical perspective that explores how organizational actors can skillfully deploy digital technology to bring about large-scale change in organizations must embrace the multiplicity of competing logics and heterogeneity of elements involved with the change. Further, this perspective should also conceptualize digital technologies as endogenous to the existing practice - simultaneously generative and 
stable - not as external forces for change. In this paper, we therefore propose a systems biology perspective inspired by the recent developments to address this gap in the literature.

\section{System Biology on Change and Stability}

An organization is comprised of various actors interacting with one another. Each actor engages in a series of actions over time and space. A change in an activity by an actor requires the actor to be adaptive to feedback from the activity. Change in the activity can influence other actors and their activities which, in turn, interact with that actor. Through this feedback, a change of an activity is occasionally amplified and can lead to the emergence of a new set of activities by a group of interconnected actors. Furthermore, the outcome of such an emergent process can often lead to unexpected and unintended consequences that can affect organizations and institutions. However, existing theories fail to offer precisely how the unexpected and novel ideas stem out from such network of actors and tools. Furthermore, a largescale institutional change rarely occurs when new technology-enabled change is introduced. Instead, new institutional orders emerge in a much more sporadic and chaotic fashion (Boland et al. 2007).

To account for this observation we adopt a systems biology perspective (Kauffman 1993, Kitano 2002). Systems biology is an attempt to systematically understand how the biological system exhibits structural stability and generativity (endogenous change) at the same time. One of the key fundamental questions that systems biology is trying to answer is how the same DNA sequence can produce many different cells that provide different functions. And, how can a single cell's behavior be affected by another cell? A systems biology perspective provides two important concepts that offers insights on how a biological system maintain a stability and generativity at the same time: gene regulatory networks and attractor.

A gene regulatory network is a collection of DNA segments (genes) in a cell that interact with each other as to govern the rate at which genes are expressed in the cell. A gene provides both structure through DNA sequences and dynamisms by regulating cellular behaviors. A gene is a segment of DNA that contains the basic genetic information of cellular behaviors to produce different proteins. Each gene has its own unique genetic information. Therefore, a gene forms the basic unit by which genetic information is inherited from one generation to another. At the same time, a gene provides another vital function as it sends instructions to produce proteins that become the basic building blocks of observed characteristics of organisms. In this process, genes are networked with other genes as they interact together to express particular functions of cells. The cell regulates each gene function, because all the genes in the network that form the phenotype function (observed characteristics) at the same time are used to express the cell behavior (Kauffman 1993). Therefore, a change in a gene triggers a sequence of changes in other genes that eventually lead to the changes in the behavior of the cells. 
In this process, a gene regulatory network plays an essential role in determining how different genes are expressed and thus produce proteins. A gene regulatory network is based on a binary function of a gene that indicates "on" if an activity is expressed and "off" if an activity is inhibited within the system. It can express a dynamic network, determining if the gene function is related to prior activity of an element in the network. Kauffman (1993) also proposes that gene regulatory networks are well-defined ensembles having both structural and behavioral features at the same time. They are based on the collective order of genes in the system. Thus, from a gene regulatory network perspective, the generativity of an organism can be understood when genes react to the environmental change by mutating.

Another important concept from a systems biology perspective is attractor (Kauffman 1993). An attractor is an element that drives a certain trajectory of change from the interaction with other elements, thus disrupting the stability of a system. Kauffman(1993) argues that an attractor can be introduced into or generated by a gene regulatory network as the system of a cell that is deterministic and repeats the recurrent state cycle. When a set of attractors are generated by the system, they can constitute a basis of attractors that can become an alternative pattern of activities in the system. To be generative, the cell system needs an attractor that coordinates the behaviors other genes in reaction to the stimulus. Therefore, an attractor in the system is a 'rogue' gene that instigates the increase of internal energy in the system (Aldana 2002). Once an attractor instigates changes in a cell system, the impact of stimulation is transferred to the other genes in the cell system. The energy transferred to others can amplify the perturbation of other genes that can in turn lead to unexpected change. Corresponding to such amplification, change can be differentiated in order to express the function as the genes are inter-dependent with one another. The expression in the gene regulatory system depends on which gene is expressed and which gene is inhibited (Crombach and Hogeweg 2008). The expressed genes form a new gene regulatory network to determine the cell behaviors stemming from their functional interdependency.

\section{Systems Biology Perspective on Institutional Change}

Inspired by the model of systems biology, we propose a new theoretical perspective anchored on institutionalism to understand changes enabled by new digital artifacts. We first conceptualize institutionalized domain of organizations to be established configurations of sociomaterial practices that involve routines of activities performed by individual actors and the repetitive patterns of interactions among actors (and also, their routines). As early as 1950, Eric Trist (1950) argued that organizations comprise of nested socio-technical systems consisting of human and technological elements "intertwined in a complex web of mutual causality" (p.13). A routine is "a repetitive, recognizable pattern of interdependent actions, involving multiple actors" (Feldman and Pentland 2003, pg. 96). More recently, Pentland et al. (2011) argues that actions in an organization are distributed over time and space, thus forming a network of activities. As such, routines that involve multiple actors performing 
different actions can be modeled as a system of actions. To be more precise, we see institutionalized practices as an equivalent of a cell system and individual routines as individual genes. A routine is further made up of individual actions and tools that are used in those actions. The performative aspect of institutionalized practices then is regulated in the way that individual routines are expressed or inhibited in an organization or a project, just like behaviors of a cell are regulated by gene expressions through a gene regulatory network.

Once we conceptualize institutionalized practices as a kind of gene regulatory network, it allows us to model the generativity resulting from the introduction of digital artifacts by treating these artifacts as attractors. That is, the modified (or mutated) routines resulting from a newly adapted digital tool as a part of it can cause a systemic change in organizations, in the same way a change in a singular rogue gene can bring about changes in a cell system. The recombinatorial nature of organizational processes from the modified routines can also create multiple connections among distributed practices. Such recombination of routines for institutionalized practiecs is possible, because of the presence of multiple actors, who have multiple views and objectives in performing those practices (Pentland and Feldman 2007). This multiplicity makes the routine system generative. During the generative process, any action (technology-in-practice) can become an attractor that can change the overall organizational process in multiple directions, whereby other actions are changed to varying degrees depending on the degree of stimulus created by the 'gene'.

This way of conceptualizing sociomaterial routines and the role of digital artifacts allows us ask a number of questions that we were not able to answer in the past. First, we are able to locate precise micro mechanisms by which an endogenous change in digital-artifacts-supported-actions by individuals in organization bring about a larger systemic change in institutionalized practices. Scholars have explored the process of such institutional entrepreneurship using varying rich metaphors such as "path creation" (Garud and Karnoe 2001) or "wakes of innovations" (Boland et al. 2007). Yet, we still do not know exactly how an action taken by an organizational actor can lead to a larger scale institutional change. Longitudinal empirical studies based on such theoretical view can provide us detailed accounts of how such processes take place. Thus, the first research question that we propose is:

Research Question 1: What are the micro mechanisms by which individual endougeous actions enacting new digital artifacts instigate larger institutional change?

We can also explore why certain routines become more generative than others, causing wider range of institutional changes. In systems biology, some attractors are more effective at transforming a system, while other attractors are not. The size of such perturbation of an attractor in a cell affects the degree of impact on another genes. The answer to this question will let us know the reasons for differential attractor impact within a cell. When an attractor starts an activity, a certain amount of counter energy is generated to maintain a state of equilibrium (Pregogine and Stengers 1984, Kauffman 1993). As the activity of an attractor increases, the tension 
between the attractor and the other genes increases. The tension remains until an attractor's energy leaps over a certain critical threshold. Then the energy dissipates to the other genes throughout the system. Thus, a new order of genes is established by expressing and inhibiting genes to achieve a new equilibrium given the increased energy. The determination of which attractor is more effective can be derived from the degree of energy needed to overcome the tension. If an attractor cannot overcome the tension, the impact is limited only to the nearby genes, which will be reordered to meet the original status quo.

Similarly, each organization shares a level of isomorphism across an institutional field, with its pervasive, or dominant, institutional logic (Thornton \& Ocasio 2008). This isomorphism is expressed in a certain set of rules that govern the organization's responses to make them fit to its resources. Each organization has therefore a certain institutional resistance that obstructs the interrelated components to be involved in change (Zucker 1977). Put it in a systems biology language, an established order of a 'gene regulatory network' directly resists the creation of novel actions. If a routine does not have potential for enough impact on other actors interconnected with it, it will not carry 'enough energy' to amplify the change among other actors. If a routine reaches sufficient energy level to overcome the conflict with the other actors, the new action will lead to broader change among the existing order leading to a larger systemic change. Unlike the systems in nature, however, the destabilization of institutionalized practices does not directly lead to a state of non-equilibrium. Routines have sedimentary traits in that the existing order is layered in practices within an institution (Seo and Creed 2002). Consequently, a dominant institutional logic in a field cannot account for every situation. In such cases, alternative, even contradictory, logics may be drawn upon by actors (Berente \& Yoo 2012). This lead to the following research question:

Research Question 2: What are the conditions under which the introduction of digital artifacts will modify existing action, or introduce a new action, within existing routines that leads to larger systemic change in the routine system?

Finally, our conceptualization invites us to explore co-evolution of digital artifacts, actions, routines and institutional order at the same time. While new genes such as digitally enabled new actions embedded in artifacts work as instructions to produce proteins that determine observable behaviors of cell systems, genes also carry genetic information over generations. This is how digital artifacts achieve their power to institutionalize existing order. In that process, however, 'digital' genes constantly mutate and recombine bringing changes to the observable traits of organizations. Like a gene's interaction with other genes, a single cell interacts all the time with other cells in an organism. For example, intercellular substances, the substances in which tissue cells are embedded, continuously interact with other cells to balance the metabolic work. The attractor can amplify the impact through the connection of other cells that causes them to show homogenized features within the organism. Once the attractor affects the other cells, the dynamic interactions among the cells are determined by the level of impact that an attractor and the feedback have on other 
genes and cells. The impact of change is related to the attractors' possibility to be reacted to by other cells (Kauffman 1993). The attractors thus have a similar nature in other cells so that the impact of the original attractor can stimulate to perturb the status quo. This happens in reactions that instigate genes near them to change the cells' expression by spontaneously organizing the order. In this regard the gene network enables the cells to sporadically respond to possible attractors spread across various cells on the impact of an attractor. This process amplifies the activity of an attractor to others by broadening the scope of change extensively.

Similarly, a gene regulatory network approach to routines allow us to model coevolutionary patterns of digital artifacts, actions, routines, and institutional orders. March (1996) argued that an activity of an actor can affect the actions of others through network structures that impact the dynamics of change. In other words, the actions within an organizational process cannot only be confined to a single boundary, but can reach out to other parts of the organization and outside to other organizations that interact with the focal organization (Orlikowiski and Scott 2008). Similar to the sporadic responses of genes through a network, this expansive activity needs to be understood in a broad sense. The impact of action variation is not only confined within an organization but should be examined across organizations. How an organization can be changed through the impact of other actors is related to the evolution of organizational learning in institutional fields. Actions, which can impact the others, have also exogenous features linked through networks across the organizations. This idea is aligned with that of Pentland and associates (2011) who suggest that an atypical action leading to the change of routine shows typically exogenous characteristics. Zucker (1977) argues that all the interconnected components in organizations are not resistant to change, but accept it as legitimate if it is 'institutionally' necessary (i.e. legitimate and viewed to have positive impacts). However, if the change is consistent with a legitimate, alternative institutional logic, actors may adopt changes if they represent valuable improvements (Powell 1991; Seo $\&$ Creed 2002). This leads us to propose the research question:

Research Question 3: What are the underlying patterns of co-evolution of digital artifacts, individual actions, routines and institutional orders?

\section{Discussion}

Consistent with the emerging intuition in information systems research that rejects to treat digital artifacts as exogenous factors, (Leonardi \& Barley 2008), digital artifacts are to be understood being embedded into routines and institutionalized practices (Orlikowski 2008). However, institutional views of organizations typically conceive technologies as exogenous to practice (if they conceive of them at all). So, the purpose of this paper is to explore how we can conceive of digital artifacts in an institutional approach whereby those artifacts are endogenous to institutionalized practice. In characterizing organizations as dynamic, evolutionary systems, we draw on systems biology to characterize institutional routines as gene regulatory networks 
and technologies-in-practice as institutional attractors. Digital artifacts as institutional attractors emerge from within an institutional practice: they are not foreign objects introduced from without, but internal reactions to either endogenous or exogenous shifts and thus drawn from within - motivated, anchored, and embedded in practice (Baxter \& Berente 2010). The digital artifacts are reinvented in practice and generate derivative innovations around that then become institutionalized. Even if digital artifacts are forced from outside of practice - the practice can loosely couple from these artifacts (Berente \& Yoo 2012) and reinvent them over time (Bourdieu \& Robey 2005). An institutional attractor is consistent with a particular institutional logic that is available in a pluralistic field (Dunn \& Jones 2010). On one hand this attractor generates change to salient practices that were previously consistent with an alternative logic, while on the other hand the attractor aids stabilizing and reinforcing the logic consistent with the attractor. From a systems biology standpoint, an institutional logic is expressed through a gene regulatory network-established patterns by which different routines interact with one another.

This view of digital artifacts as institutional attractors has implications methodologically. Historically researchers have looked to understand social change through either a structural lens or a sequential lens. Structural analysis involves cross-sectional analysis of relationships between elements of social systems - what Sandberg \& Tsoukas (2011) refer to as "entity-based approaches." This could involve variance theories of relationships between latent factors (Van de Ven 2007), or social network analyses of relationships between social actors (Monge \& Contractor 2003). In either case, change is accounted for by contingency variables and comparison of cross-sectional structures. An alternative way of viewing social activity is by expressly attending to temporal elements of activities - as processes described by patterns of events (Van de Ven \& Poole 1995) or sequences of activities (Abbott 1995). These methods capture patterns of change, but do so at the expense of rich contextual attention (Pentland \& Feldman 2007). Emerging sociomaterial approaches are adding cross-sectional context to sequence approaches (Pentland et al 2012; Gaskin et al 2011), or adding temporal elements to multimodal networks (resulting in "multidimensional" networks, see Contractor et al 2011).

Essentially we need to combine "zooming in" to practice and "zooming out" to regularities across practices (Sandberg \& Tsoukas 2011; Latour 2010). By thinking of digital artifacts as institutional attractors, we enable this zooming in and out using the multilevel device of an institutional logic (Friedland \& Alford 1991). Institutional attractors embedded in practice work to co-constitute the stabilization and change associated with those practices in a way consistent with particular logics that are rooted in society's broader institutions (Berente \& Yoo 2012).

By drawing on a systems biology perspective, our approach also offers ways to utilize contemporary computational techniques that are often used to analyze largescale genetic information. Our approach necessitates new forms of methodological tools and analytical frameworks that simultaneously consider both sequential and structural data. Combined with increasingly available digital trace data from organizations, we can explore how seemingly chaotic and random changes of sociomaterial routines in organizations emerge from recombinations of relatively 
small set of abstract genetic elements. Recently, scholars offer an idea of computational social science that combines the availability of 'big data' from digital archives and computational network science (Lazer et al. 2009). Our view suggests an alternative approach to computational social science that focuses on the genetics and evolution; one that embraces both sequence analysis and network analysis simultaneously.

\section{Conclusion}

IFIP 8.2 has historically been a venue for novel theoretical combinations and alternative research methodologies (Boland \& Lyytinen 2004). In this paper we look to draw on and extend this tradition by juxtaposing concepts from system biology and organizational institutionalism. In doing so we look to add one perspective in the emerging movement in IS research to go beyond idiosyncratic local practices, while not falling victim to decontextualized universal generalities (Leonardi \& Barley 2008; Pollock \& Williams 2009). This paper argues for an evolutionary view of how an activity can lead endogenous changes to routines within an organization through networks of influence. Here in particular, the digital artifact can become a tool that both stabilizes patterns of action and at the same time generates changes in organizational routines through diverse enactments of various scales. This view implies a combined sociomaterial routine and multidimensional network view of organizational practice which would call for combined sequence and network methods that include digital artifacts as key actants - a theoretical foundation for some of the emerging methodological innovations of recent years (Contractor et al 2011; Pentland et al 2008; Gaskin et al 2011). It is our hope that this initial step can provide the scaffolding for future researchers to explore and extend theoretically and with novel methodological applications.

\section{References}

Aldana, M.: Dynamics of Boolean networks with scale-free topology. Arxiv preprint condmat/0209571 (2002)

Avital, M., Boland, R.J., et al.: Introduction to designing information and organizations with a positive lens. Information and Organization 19(3), 153-161 (2009)

Bailey, D.E., Leonardi, P.M., et al.: The lure of the virtual. Organization Science 23(5), 14851504 (2012)

Baxter, R.J., Berente, N.: The process of embedding new information technology artifacts into innovative design practices. Information and Organization 20(3), 133-155 (2010)

Barley, S.R.: Technology as an occasion for structuring: Evidence from observations of CT scanners and the social order of radiology departments. Administrative Science Quarterly, 78-108 (1986)

Berger, P.L., Luckmann, T.: The Social Construction of Reality (1966)

Boland, R., Lyytinen, K.: Information systems research as design: Identity, process, and narrative. Information Systems Research, 53-68 (2004) 
Boland, R.J., Lyytinen, K., et al.: Wakes of innovation in project networks: the case of digital 3-D representations in architecture, engineering, and construction. Organization Science 18(4), 631-647 (2007)

Bourdieu, P.: The economics of linguistic exchanges. Social Science Information 16(6), 645668 (1977)

Boudreau, M.C., Robey, D.: Enacting integrated information technology: A human agency perspective. Organization Science 16(1), 3-18 (2005)

Berente, N., Yoo, Y.: Institutional Contradictions and Loose Coupling: Postimplementation of NASA's Enterprise Information System. Information Systems Research (2012)

Contractor, N., Monge, P.R., et al.: Multidimensional networks and the dynamics of sociomateriality: Bringing technology inside the network. International Journal of Communication 5, 682-720 (2011)

Crombach, A., Hogeweg, P.: Evolution of evolvability in gene regulatory networks. PLoS Computational Biology 4(7), e1000112 (2008)

Czarniawska-Joerges, B., Sevón, G.: Translating organizational change. de Gruyter (1996)

DeSanctis, G., Poole, M.S.: Capturing the complexity in advanced technology use: Adaptive structuration theory. Organization Science, 121-147 (1994)

DiMaggio, P.J., Powell, W.W.: The iron cage revisited: Institutional isomorphism and collective rationality in organizational fields. American Sociological Review, 147-160 (1983)

DiMaggio, P.J.: Interest and agency in institutional theory. Institutional Patterns and Organizations, 3-21 (1988)

Dunn, M.B., Jones, C.: Institutional logics and institutional pluralism: The contestation of care and science logics in medical education, 1967-2005. Administrative Science Quarterly 55(1), 114-149 (2010)

Farjoun, M.: Beyond dualism: Stability and change as a duality. The Academy of Management Review (AMR) 35(2), 202-225 (2010)

Feldman, M.S., Pentland, B.T.: Reconceptualizing organizational routines as a source of flexibility and change. Administrative Science Quarterly 48(1), 94-118 (2003)

Friedland, R., Alford, R.R., et al.: The new institutionalism in organizational analysis. The New Institutionalism in Organizational Analysis (1991)

Gaskin, J., Thummadi, B.V., et al.: Digital Technology and the Variation in Design Routines: A Sequence Analysis of Four Design Processes1 (2011)

Garud, R., Karnøe, P.: Path creation as a process of mindful deviation. Path Dependence and Creation 138 (2001)

Garud, R., Jain, S., et al.: Institutional entrepreneurship in the sponsorship of common technological standards: The case of Sun Microsystems and Java. Academy of Management Journal, 196-214 (2002)

Garud, R., Karnøe, P.: Path creation as a process of mindful deviation. Path Dependence and Creation 138 (2001)

Giddens, A.: The constitution of society: Outline of the theory of structuration. Univ. of California Press (1984)

Goffman, E.: Strategic interaction. University of Pennsylvania Press (1969)

Greenwood, R., Oliver, C., et al.: Organizational Institutionalism. Sage, Los Angelos (2008)

Jepperson, R.L.: Institutions, institutional effects, and institutionalism. The New Institutionalism in Organizational Analysis 6, 143-163 (1991)

Jones, M.R., Karsten, H.: Giddens's structuration theory and information systems research. Mis Quarterly 32(1), 127-157 (2008)

Kauffman, S.A.: The origins of order. Oxford University Press, New York (1993) 
Kallinikos, J., Mariátegui, J.C.: Video as digital object: production and distribution of video content in the internet media ecosystem. The Information Society 27(5), 281-294 (2011)

Kitano, H.: Systems biology: a brief overview. Science 295(5560), 1662-1664 (2002)

Kraatz, M.S., Block, E.S.: Organizational implications of institutional pluralism. The Sage Handbook of Organizational Institutionalism 840 (2008)

Lazer, D., Pentland, A.S., et al.: Life in the network: the coming age of computational social science. Science (New York, NY) 323(5915), 721 (2009)

Leonardi, P.M., Barley, S.R.: Materiality and change: Challenges to building better theory about technology and organizing. Information and Organization 18(3), 159-176 (2008)

Leonardi, P.: When flexible routines meet flexible technologies: Affordance, constraint, and the imbrication of human and material agencies. Mis Quarterly 35(1), 147-167 (2011)

March, J.G.: Continuity and change in theories of organizational action. Administrative Science Quarterly, 278-287 (1996)

Meyer, J.W., Rowan, B.: Institutionalized organizations: Formal structure as myth and ceremony. American Journal of Sociology, 340-363 (1977)

Monge, P.R., Contractor, N.S.: Theories of communication networks. Oxford University Press, USA (2003)

Orlikowski, W.J.: Using Technology and Constituting Structures: A Practice Lens for Studying Technology in Organizations. Organization Science 11(4), 405 (2000)

Orlikowski, W.J., Scott, S.V.: 10 Sociomateriality: Challenging the Separation of Technology, Work and Organization. The Academy of Management Annals 2(1), 433-474 (2008)

Orlikowski, W.J.: Using technology and constituting structures: A practice lens for studying technology in organizations. Resources, Co-Evolution and Artifacts, 255-305 (2008)

Pentland, B.T., Feldman, M.S.: Organizational routines as a unit of analysis. Industrial and Corporate Change 14(5), 793-815 (2005)

Pentland, B.T., Feldman, M.S.: Narrative networks: Patterns of technology and organization. Organization Science 18(5), 781-795 (2007)

Pentland, B.T., Feldman, M.S.: Designing routines: On the folly of designing artifacts, while hoping for patterns of action. Information and Organization 18(4), 235-250 (2008)

Pentland, B.T., Hærem, T., et al.: The (N) Ever-Changing World: Stability and Change in Organizational Routines. Organization Science 22(6), 1369-1383 (2011)

Pentland, B.T., Feldman, M.S., et al.: Dynamics of organizational routines: a generative model. Journal of Management Studies (2012)

Pollock, N., Williams, R.: The sociology of a market analysis tool: How industry analysts sort vendors and organize markets. Information and Organization 19(2), 129-151 (2009)

Powell, W.W., DiMaggio, P.J.: The new institutionalism in organizational analysis. University of Chicago Press (1991)

Progogine, I., Stengers, I.: Order out of chaos: Man's new dialogue with nature. Fontana, London (1984)

Rao, H., Morrill, C., et al.: Power plays: How social movements and collective action create new organizational forms. Research in Organizational Behavior 22, 237-282 (2000)

Robey, D., Boudreau, M.C.: Accounting for the contradictory organizational consequences of information technology: Theoretical directions and methodological implications. Information Systems Research 10(2), 167 (1999)

Sandberg, J., Tsoukas, H.: Grasping the logic of practice: Theorizing through practical rationality. The Academy of Management Review (AMR) 36(2), 338-360 (2011)

Scott, W.R.: Institutions and Organizations. Sage, Thousand Oaks (2001)

Scott, W.R.: Lords of the dance: Professionals as institutional agents. Organization Studies 29(2), 219-238 (2008) 
Selznick, P.: Institutionalism "old" and "new". Administrative Science Quarterly, 270-277 (1996)

Seo, M.G., Creed, W.E.D.: Institutional contradictions, praxis, and institutional change: A dialectical perspective. Academy of Management Review, 222-247 (2002)

Teece, D.J.: Profiting from technological innovation: Implications for integration, collaboration, licensing and public policy. Research Policy 15(6), 285-305 (1986)

Thornton, P., Ocasio, W., et al.: The handbook of organizational institutionalism. Sage (2008)

Trist, E.: The relations of social and technical systems in coal-mining. British Psychological Society, Industrial Section (1950)

Van de Ven, A.H., Poole, M.S.: Explaining development and change in organizations. Academy of Management Review, 510-540 (1995)

Van de Ven, A.H.: Engaged scholarship: A guide for organizational and social research. OUP Oxford (2007)

Yoo, Y., Henfridsson, O., et al.: Research Commentary-The New Organizing Logic of Digital Innovation: An Agenda for Information Systems Research. Information Systems Research 21(4), 724-735 (2010)

Yoo, Y., Boland Jr, R.J., et al.: From organization design to organization designing. Organization Science, 215-229 (2006)

Zammuto, R.F., Griffith, T.L., et al.: Information technology and the changing fabric of organization. Organization Science 18(5), 749-762 (2007)

Zittrain, J.L.: The generative internet. Harvard Law Review, 1974-2040 (2006)

Zucker, L.G.: The role of institutionalization in cultural persistence. American Sociological Review, 726-743 (1977) 